\title{
EVALUASI PEMAHAMAN MAHASISWA DALAM PROSES KNOWLEDGE SHARING MELALUI BERBAGAI PLATFORM DIGITAL MENGGUNAKAN METODE COLLES
}

\author{
Mei Lenawati \\ Sistem Informasi, Universitas PGRI Madiun, Madiun, Indonesia \\ mei.lenawati@unipma.ac.id
}

\begin{abstract}
Abstrak
Knowledge sharing yang merupakan bagian dari Knowledge Management (KM) banyak diterapkan di berbagai organisasi, termasuk di institusi pendidikan. Di lingkungan pendidikan KM sering disebut dengan Learning Management System atau dikenal sebagai sistem e-learning. Penerapan e-learning di institusi pendidikan sering mengalami kegagalan karena penggunannya kurang merasa nyaman dengan sistem. Penelitian ini bertujuan untuk mengukur tingkat kenyamanan penggunaan sistem daring yaitu mahasiswa di Universitas PGRI Madiun terutama untuk mendukung kelancaran proses knowledge sharing antara dosen dan mahasiswa dengan menerapkan multi platform digital yaitu elma, Whatshaap, Google Classroom dan Zoom dengan menggunakan kuesioner format COLLES. Dari seluruh hasil perhitungan skor evaluasi diketahui skor tertinggi berada pada platform Google classroom (89\%), yang diikuti oleh platform Whats App (80,78\%), ZOOM (80,44\%) dan ELMA $(73,89)$.
\end{abstract}

Kata kunci : knowledge sharing, colles, mahasiswa, e-learning, digital platform

\begin{abstract}
Knowledge sharing which is part of Knowledge Management (KM) is widely applied in various organizations, including in educational institutions. In the educational environment $\mathrm{KM}$ is often referred to as a Learning Management System or known as an e-learning system. The application of e-learning in educational institutions often fails because its users are not comfortable with the system. This study aims to measure the comfort level of using the online system, namely students at PGRI Madiun University, especially to support the smooth process of knowledge sharing between lecturers and students by implementing multi digital platforms, namely Elma, Whatshaap, Google Classroom and Zoom using a COLLES format questionnaire. From all the results of the calculation of the evaluation score, it is known that the highest score is on the Google classroom platform (89\%), followed by the Whats App platform $(80.78 \%)$, ZOOM (80.44\%) and ELMA (73.89).
\end{abstract}

Keywords: knowledge sharing, colles, students, e-learning, digital platform

\section{Pendahuluan}

Penyebaran Virus Corona COVID-19 diberbagai belahan dunia berdampak bagi masyarakat dan berbagai sektor kehidupan, termasuk salah satunya sektor pendidikan, pengguna elearning di masa pandemi Covid-19 meningkat pesat. Hal itu dikarenakan adanya kebijakan WFH (work from home) dari pemerintah, sehingga seluruh proses kegiatan pembelajaran di kelas digantikan dengan model pembelajaran secara online atau pendidikan Jarak Jauh (PJJ) (Rusdiana, Sulhan, Zaenal, \& Ahmad, 2020).

Universitas PGRI Madiun merupakan salah satu universitas swasta di Jawa Timur yang menerapkan kebijakan perkuliahan secara online dan Work From Home (WFH) selama masa pandemi. Pembelajaran secara online yang dilakukan saat ini tidak hanya menggunakan e-learning yang disediakan oleh kampus, namun beberapa dosen menggunakan platform digital lain seperti
Whatshapp, Google Classroom dan Zoom (D. Setiawan, 2020).

Knowledge sharing yang merupakan bagian dari Knowledge Management (KM) banyak diterapkan di berbagai organisasi, termasuk di institusi pendidikan (Zahari, Salleh, \& Baniamin, 2020). Di lingkungan pendidikan Knowledge Management (KM) sering disebut dengan Learning Management System atau dikenal sebagai sistem elearning (D. Setiawan, 2018). Dengan e-learning berbasis knowledge Mahasiswa dapat saling berbagi informasi atau pendapat mengenai berbagai hal yang menyangkut pelajaran dan kebutuhan lain untuk pengembangan diri mahasiswa. Dosen dapat menempatkan bahan ajar secara online yang dapat didownload oleh mahasiswa, dan pemberian tugas kepada mahasiswa serta pengumpulannya melalui sistem (Evrilyan Rozanda \& Wahyuningsih, 2017).

Namun dalam Penerapannya sistem e-learning di institusi pendidikan sering mengalami kegagalan, hal ini dikarenakan para pengguna kurang merasa 
nyaman dengan teknologi dan sistem yang digunakan (D. Setiawan \& Wicaksono, 2020). Sehingga diperlukan sebuah evaluasi guna mengukur pemahaman dari penggunaan berbagai platform yang digunakan untuk keperluan pembelajaran, salah satunya dengan menggunakan metode Contructivist On-line Learning Environtment Survey (COLLES).

Metode Contructivist On-line Learning Environtment Survey (COLLES) merupakan metode yang dikembang-kan oleh Peter Charles Taylor dan Dorit Maor dari Curtin University of technology Australia dalam rangka mengukur sejauh mana sistem pembelajaran dapat memperkaya pengetahuan mahasiswa (Budiarti, 2016). Dan nantinya metode ini akan digunakan untuk melakukan evaluasi berbagai platform digital yang digunakan dalam proses pembelajaran yaitu Elma, Whatshapp, Google classroom dan Zoom.

\section{Landasan Teori}

\subsection{Platform Digital untuk Pembelajaran}

Platform Digital untuk Pembelajaran dapat diartikan sebagai berbagai macam media / sistem yang digunakan untuk membantu keberlangsungan proses pembelajaran secara digital. untuk studi kasus di Universitas PGRI Madiun platform yang biasa digunakan untuk kegiatan pembelajaran diantaranya adalah E-Learning UNIPMA yang dikembangkan dengan moodle dan diberi nama ELMA (D. Setiawan \& Rafianto, 2020). social media Whatshapp, Google classroom dan Zoom teleconference.

\subsection{Metode Contructivist On-line Learning Envi- rontment Survey (COLLES)}

Merupakan Sebuah metode yang digunakan untuk mengukur sejauh mana sistem pembelajaran dapat memperkaya pengetahuan mahasiswa, metode ini dikembang-kan oleh Peter Charles Taylor dan Dorit Maor dari Curtin University of technology Australia. (Budiarti, 2016)

COLLES memiliki 3 jenis survey yakni prefered form, actual form dan kombinasi keduanya. Prefered form menekankan pada opini ideal yang dimiliki mahasiswa dalam pembelajaran online, sementara actual form lebh kepada pengalaman aktual dan nyata yang dialami selama pembelajaran. Dari ketiga jenis survey penelitian ini menggunakan kombinasi dari prefered form dan actual form dengan tujuan segala bentuk opini pada mahasiswa dapat terakomodasi dengan baik.(Ratnasari, 2016)

Metode ini merupakan metode penelitian yang difokuskan pada kuisioner yang digunakan untuk mengetahui tingkat kenyamanan penggunaan sistem pembelajaran online oleh pengajar dan pelajar dalam mendukung proses Knowledge Sharing. Metode ini memiliki 6 kategori pertanyaan yang menggambarkan penggunaan sistem pembelajaran online diantaranya relevance, Reflection Thinking, Interactive, Tutor Support, Peer Support, dan Interpretation (J. Setiawan, Ente, \& Interface, 2017)

Adapun penjelasan lebih detail tentang 6 kategori di dalam metode COLLES, diantaranya :

1. Relevance, yaitu seberapa relevan (kesesuaian)

2. antara sistem elearning dengan tingkat knowledge pengguna.

3. Reflection, yaitu kemampuan sistem e-learning dalam merangsang siswa untuk berfikir kritis dan terbuka.

4. Interactivity, yaitu sejauh mana siswa dapat berpartisipasi (berinteraksi) dalam proses pertukaran knowledge melalui sistem elearning.

5. Tutor Support yaitu seberapa jauh pengajar memberi kesempatan kepada siswa untuk berpartisipasi dalam sistem e-learning.

6. Peer Support, yaitu besarnya dukungan antar sesama siswa dalam sistem e-learning.

7. Interpretation yaitu kesamaan tingkat pemahaman pengajar dan siswa dalam berkomunikasi secara Online (Aditra \& Ardwi, 2016).

\section{Metode Penelitian}

\subsection{Pengumpulan Data}

Untuk tahap pengumpulan data dilakukan beberapa kegiatan yaitu studi pustaka dan Observasi. studi pustaka dilakukan dengan cara mempelajari referensi berupa jurnal penelitian serta artikel lainnya yang berhubungan dengan knowledge sharing dan platform digital e-learning sehingga membantu peneliti dalam penyusunan penelitian. Sedangkan untuk observasi adalah kegiatan yang dilakukan dengan cara mengamati kondisi dari lingkungan yang diteliti secara langsung.

Setelah melakukan pengumpulan data selanjutnya menentukan jumlah responden menggunakan rumus slovin. Responden diambil dari sampel 30 mahasiswa dari jumlah populasi 50 orang dengan perhitungan Slovin pada Persamaan 1 (D. Setiawan \& Rafianto, 2020)

$$
n=\frac{N}{1+N(e)^{2}}
$$

Dimana $\mathrm{n}$ adalah ukuran sampel, $\mathrm{n}=$ Ukuran sampel, $\mathrm{N}=$ Ukuran populasi, e = Taraf kesalahan error sebesar $0,1(10 \%)$

Responden berstatus aktif kuliah yang terdiri dari mahasiswa lintas angkatan dari program studi Sistem Informasi Universitas PGRI Madiun yang terdiri dari 30 mahasiswa yang dijadikan responden terdiri dari 15 pria dan 15 wanita. 13 mahasiswa dari angkatan semester 6, 12 mahasiswa dari angkatan semester 4, dan 5 mahasiswa dari angkatan semester 2. Responden telah mulai memakai memakai 
berbagai macam paltform digital pembelajaran semenjak bulan Maret 2020.

3.2. Evaluasi dengan Metode Contructivist Online Learning Envi-rontment Survey (COLLES)

Pada tahap ini dilakukan evaluasi dengan melakukan pembuatan \& pembagian kuisioner kepada responden terpilih dimana didalamnya terdapat 6 pertanyaan yang mengandung unsur 6 kategori COLLES sendiri dari mulai (1) relevance, (2) Reflection Thinking, (3) Interactive, (4) Tutor Support, (5) Peer Support, dan (6) Interpretation. Pertanyaan ini nantinya didihitung menggunakan perhitungan skala likert dengan 5 kriteria jawaban yang dapat dilihat pada Tabel 1.

Tabel 1. Kuisioner COLLES

\begin{tabular}{|l|l|l|l|l|l|l|}
\hline \multirow{2}{*}{ No } & \multicolumn{1}{|c|}{ Pertanyaan } & \multicolumn{1}{c|}{ Kriteria Jawaban } \\
\cline { 3 - 6 } & & $\begin{array}{c}\text { Tidak } \\
\text { Pernah } \\
(1)\end{array}$ & $\begin{array}{c}\text { Jarang } \\
\text { (2) }\end{array}$ & $\begin{array}{c}\text { Kadang } \\
\text { (3) }\end{array}$ & $\begin{array}{c}\text { Sering } \\
(4)\end{array}$ & $\begin{array}{c}\text { Selalu } \\
\text { (5) }\end{array}$ \\
\hline 1 & $\begin{array}{l}\text { Seberapa relevan (kesesuaian) antara paltform } \\
\text { yang digunakan dengan tingkat Pemahaman } \\
\text { pengguna? }\end{array}$ & & & & \\
\hline 2 & $\begin{array}{l}\text { Apakah paltform yang digunakan dapat } \\
\text { merangsang siswa untuk berfikir kritis dan } \\
\text { terbuka? }\end{array}$ & & & & & \\
\hline 3 & $\begin{array}{l}\text { Sejauh mana pengajar memberi kesempatan } \\
\text { kepada siswa untuk berpartisipasi (berinteraksi) } \\
\text { dalam proses pertukaran knowledge melalui } \\
\text { paltform tersebut? }\end{array}$ & & & & & \\
\hline 4 & $\begin{array}{l}\text { Seberapa jauh pengajar memberi kesempatan } \\
\text { kepada siswa untuk berpartisipasi dalam } \\
\text { pengunaan platform? }\end{array}$ & & & & & \\
\hline 5 & $\begin{array}{l}\text { Bagaimana dukungan antar sesama siswa dalam } \\
\text { paltform yang digunakan? }\end{array}$ & & & & & \\
\hline 6 & $\begin{array}{l}\text { Apakah siswa dan pengajar memiliki } \\
\text { pemahaman yang sama dalam berkomunikasi } \\
\text { secara online? }\end{array}$ & & & & & \\
\hline
\end{tabular}

\subsection{Metode Analisis Data}

Pada tahap ini dilakukan perhitungan penentuan skor jawaban dari kuisioner yang diberkan kepada responden. Adapun langkahnya dimulai dengan melakukan perhitungan jumlah Skor ideal yang di dapat dari perkalian dari jumlah skor maksimal masing masing responden dengan jumlah responden, yang selanjutnya dilakukan pencarian nilai hasil prosentase dari keseluruhan responden terhadap satu platform, yang kemudian didapatkan rating skala berdasarkan skor ideal dari 30 responden adalah sebesar 900 dan keterangannya yang dapat dilihat pada Tabel 2.

Tabel 2. Rating skala

\begin{tabular}{|c|c|c|l|}
\hline $\begin{array}{c}\text { Interval } \\
\text { Nilai }\end{array}$ & Prosentase & $\begin{array}{c}\text { Rating } \\
\text { skala }\end{array}$ & $\begin{array}{c}\text { Membantu proses } \\
\text { Knowledge } \\
\text { Sharing }\end{array}$ \\
\hline $0-180$ & $0 \%-20 \%$ & 1 & Sangat Kurang \\
\hline $181-360$ & $21 \%-40 \%$ & 2 & Kurang \\
\hline $361-540$ & $41 \%-60 \%$ & 3 & Cukup \\
\hline $541-720$ & $61 \%-80 \%$ & 4 & Bagus \\
\hline $721-900$ & $81 \%-100 \%$ & 5 & Sangat Bagus \\
\hline
\end{tabular}

\section{Hasil \& Pembahasan}

Pada hasil dan pembahasan disajikan beberapa hasil tabel rekapitulasi dari penyebaran kuisioner dengan menggunakan metode COLLES.

Berikut adalah Tabel 3. yang merupakan hasil perhitungan dari platform ELMA :

Tabel 3. Hasil perhitungan platform ELMA

\section{Platform ELMA}

\begin{tabular}{|l|r|r|r|r|r|r|r|}
\hline \multicolumn{7}{|c|}{ Platform ELMA } \\
\hline R1 & 3 & 3 & 4 & 4 & 3 & 3 & 20 \\
\hline R2 & 4 & 3 & 4 & 4 & 3 & 3 & 21 \\
\hline R3 & 3 & 5 & 4 & 4 & 3 & 3 & 22 \\
\hline R4 & 4 & 5 & 5 & 4 & 3 & 3 & 24 \\
\hline R5 & 5 & 3 & 5 & 4 & 3 & 4 & 24 \\
\hline R6 & 3 & 5 & 5 & 3 & 3 & 4 & 23 \\
\hline R7 & 5 & 5 & 5 & 3 & 3 & 4 & 25 \\
\hline R8 & 5 & 5 & 4 & 4 & 3 & 4 & 25 \\
\hline R9 & 4 & 4 & 4 & 5 & 3 & 4 & 24 \\
\hline R10 & 5 & 4 & 4 & 3 & 3 & 5 & 24 \\
\hline R30 & 5 & 3 & 5 & 5 & & & Q \\
\hline \multicolumn{7}{|c|}{ Perhitungan Skor } \\
\hline
\end{tabular}


Dari hasil perhitungan skor terhadap paltform ELMA dapat diketahui bahwa platform ini memiliki jumlah skor sebesar 665 dengan prosentase $73,89 \%$ masuk dalam kategori rating skala 4 dengan masuk ke dalam kategori patform dengan keterangan "Bagus dalam membantu proses knowledge sharing".

Selanjutnya untuk platform Google Classroom didapat hasil sebagai berikut :

Tabel 4. Hasil perhitungan platform G-class Platform Google Classroom

\begin{tabular}{|c|c|c|c|c|c|c|c|}
\hline & Q1 & Q2 & Q3 & Q4 & Q5 & Q6 & $\begin{array}{c}\text { Jumlah } \\
\text { Skor }\end{array}$ \\
\hline R1 & 4 & 4 & 4 & 4 & 4 & 4 & 24 \\
\hline R2 & 4 & 5 & 4 & 4 & 5 & 5 & 27 \\
\hline R3 & 5 & 5 & 4 & 4 & 5 & 5 & 28 \\
\hline R4 & 4 & 5 & 5 & 4 & 5 & 5 & 28 \\
\hline R5 & 4 & 4 & 4 & 4 & 4 & 4 & 24 \\
\hline R6 & 4 & 5 & 4 & 4 & 5 & 5 & 27 \\
\hline R7 & 5 & 5 & 4 & 4 & 5 & 5 & 28 \\
\hline R8 & 4 & 5 & 5 & 4 & 5 & 5 & 28 \\
\hline R9 & 4 & 4 & 4 & 4 & 4 & 4 & 24 \\
\hline R10 & 4 & 5 & 4 & 4 & 5 & 5 & 27 \\
\hline R30 & 5 & 4 & 5 & 5 & 4 & 4 & 27 \\
\hline & 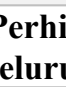 & & & & & & 801 \\
\hline
\end{tabular}

Dari hasil perhitungan skor terhadap paltform Google Classroom dapat diketahui bahwa platform ini memiliki jumlah skor sebesar 801 dengan prosentase $89 \%$ masuk dalam kategori rating skala 5 dengan masuk ke dalam kategori patform dengan keterangan "Sangat Bagus dalam membantu proses knowledge sharing".

Untuk Platform Whats App didapat hasil sebagai berikut :

Tabel 5. Hasil perhitungan platform WhatsApp

\begin{tabular}{|c|c|c|c|c|c|c|c|}
\hline \multicolumn{8}{|c|}{ Platform Whats App } \\
\hline & Q1 & Q2 & Q3 & Q4 & Q5 & Q6 & $\begin{array}{c}\text { Jumlah } \\
\text { Skor }\end{array}$ \\
\hline R1 & 4 & 3 & 4 & 4 & 4 & 4 & 23 \\
\hline R2 & 4 & 4 & 3 & 4 & 5 & 3 & 23 \\
\hline R3 & 4 & 4 & 4 & 4 & 3 & 5 & 24 \\
\hline R4 & 4 & 3 & 5 & 4 & 5 & 5 & 26 \\
\hline R5 & 4 & 3 & 3 & 4 & 4 & 3 & 21 \\
\hline R6 & 4 & 3 & 4 & 4 & 3 & 5 & 23 \\
\hline R7 & 4 & 5 & 4 & 4 & 5 & 5 & 27 \\
\hline R8 & 4 & 5 & 3 & 4 & 5 & 5 & 26 \\
\hline R9 & 4 & 4 & 3 & 4 & 4 & 3 & 22 \\
\hline R10 & 4 & 5 & 4 & 3 & 3 & 5 & 24 \\
\hline R30 & 4 & 4 & 5 & 5 & 4 & 3 & 25 \\
\hline & $\begin{array}{l}\text { erhit } \\
\text { luru }\end{array}$ & $\begin{array}{l}\text { ngar } \\
\text { an r }\end{array}$ & $\begin{array}{l}\text { Skor } \\
\text { pont }\end{array}$ & & & & 727 \\
\hline
\end{tabular}

Dari hasil perhitungan skor terhadap paltform Whats App dapat diketahui bahwa platform ini memiliki jumlah skor sebesar 727 dengan prosentase $80,78 \%$ masuk dalam kategori rating skala 4 dengan masuk ke dalam kategori patform dengan keterangan "Bagus dalam membantu proses knowledge sharing".

Untuk platform ZOOM didapat hasil sebagai berikut :

Tabel 6. Hasil perhitungan platform ZOOM

\begin{tabular}{|c|c|c|c|c|c|c|c|}
\hline \multicolumn{8}{|c|}{ Platform Zoom } \\
\hline & Q1 & Q2 & Q3 & Q4 & Q5 & Q6 & $\begin{array}{c}\text { Jumlah } \\
\text { Skor }\end{array}$ \\
\hline R1 & 3 & 3 & 4 & 4 & 4 & 4 & 22 \\
\hline $\mathbf{R 2}$ & 4 & 3 & 4 & 4 & 5 & 4 & 24 \\
\hline R3 & 4 & 3 & 4 & 4 & 3 & 5 & 23 \\
\hline R4 & 5 & 3 & 4 & 4 & 5 & 4 & 25 \\
\hline R5 & 4 & 5 & 4 & 4 & 4 & 4 & 25 \\
\hline R6 & 4 & 5 & 4 & 4 & 3 & 5 & 25 \\
\hline R7 & 5 & 5 & 4 & 4 & 5 & 4 & 27 \\
\hline R8 & 4 & 5 & 4 & 4 & 5 & 5 & 27 \\
\hline R9 & 4 & 5 & 3 & 4 & 4 & 4 & 24 \\
\hline R10 & 5 & 5 & 4 & 3 & 3 & 5 & 25 \\
\hline R30 & 4 & 4 & 5 & 5 & 4 & 3 & 25 \\
\hline & $\begin{array}{l}\text { erhit } \\
\text { luru }\end{array}$ & $\begin{array}{l}\text { ngal } \\
\text { an } \mathbf{r}\end{array}$ & Skol & & & & 724 \\
\hline
\end{tabular}

Dari hasil perhitungan skor terhadap paltform ZOOM dapat diketahui bahwa platform ini memiliki jumlah skor sebesar 724 dengan prosentase $80,44 \%$ masuk dalam kategori rating skala 4 dengan masuk ke dalam kategori patform dengan keterangan "Bagus dalam membantu proses knowledge sharing".

\section{Kesimpulan}

Dari hasil perhitungan evaluasi pemahaman mahasiswa dalam proses knowledge sharing melalui berbagai platform digital menggunakan metode COLLES didapat hasil sebagai berikut :

1. Platform ELMA, ZOOM, dan Whatsapp masuk dalam kategori platform yang bagus dalam membantu proses kowledge sharing dengan prosentase masing masing sebesar $73,89 \%$ untuk ELMA, 80,78\% untuk whats App, 80,44 \% untuk ZOOM.

2. Platform Google Classroom masuk ke dalam kategori platform yang Sangat bagus dalam membantu proses knowledge Sharing dengan prosentase sebesar $89 \%$.

3. Dari seluruh hasil perhitungan skor diatas diketahui skor tertinggi berada pada platform Google classroom (89\%), yang diikuti oleh platform Whats App (80,78\%), ZOOM (80,44\%) dan ELMA $(73,89)$. 


\section{Daftar Pustaka:}

Aditra, G., \& Ardwi, I. M., 2016, Implementasi Responsive E-learning Berbasis MOODLE Untuk Menunjang Kegiatan Pembelajaran di STMIK STIKOM Indonesia. Jurnal Ilmu Komputer Dan Sains Terapan, 5(2), 127-135.

Budiarti, Y, 2016, Penerapan Knowledge Management System pada E-Learning dengan Metode COLLES Untuk meningkatkan hasil belajar siswa. IJSE - Indonesian Journal on Software Engineering Penerapan, 1(1), 36-41.

Evrilyan Rozanda, N., \& Wahyuningsih, R., 2017, Penerapan Knowledge Transfer Pada E-learning. Seminar Nasional Teknologi Informasi, 2579-5406.

Ratnasari, A., 2016, STUDI PENGARUH PENERAPAN E-LEARNING TERHADAP KEAKTIFAN STUDI KASUS UNIVERSITAS MERCU BUANA JAKARTA. In Seminar Nasional Aplikasi Teknologi Informasi (Vol. 2016, pp. 15-16).

Rusdiana, A., Sulhan, M., Zaenal, I., \& Ahmad, A. U, 2020, Penerapan Model POE2WE Berbasis Blended Learning Google Classroom Pada Pembelajaran Masa WFH Pandemic Covid-19, 110.

Setiawan, D, 2018, ANALISIS KEBUTUHAN E-
LEARNING PROGRAM STUDI SISTEM INFORMASI UNIVERSITAS PGRI MADIUN. SENATIK, 30-36.

Setiawan, D, 2020, Evaluasi Usability E-Learning Moodle Dan Google Classroom Menggunakan Sus Questionnaire. Jami, 1(1), 55-64.

Setiawan, D., \& Rafianto, N., 2020, Pengukuran usability pada learning management system perguruan tinggi menggunakan pedoman system usability scale Usability measurement in college learning management system using the guidance system usability scale, 10(1), 23-31.

Setiawan, D., \& Wicaksono, S. L., 2020, Evaluasi Usability Google Classroom Menggunakan System Usability Scale, 2(1), 71-78.

Setiawan, J., Ente, S., \& Interface, U, 2017, EVALUASI PEMAHAMAN PENGGUNAAN ELEARNING BERBASIS MOODLE, (October 2015), 0-5.

Zahari, A. S. M., Salleh, S. M., \& Baniamin, R. M. R, 2020, Knowledge Management and e-Learning in Organisations. Journal of Physics: Conference Series, 1529(2). https://doi.org/10.1088/1742$6596 / 1529 / 2 / 022051$ 